\title{
$S$-RNase allele identification and incompatibility group assignment in apricot cultivars
}

\author{
S. Herrera ${ }^{1}$, J. Rodrigo ${ }^{1}$, J.I. Hormaza ${ }^{2}$, M. Herrero ${ }^{3}$ and J. Lora $2 \mathrm{a}$ \\ 1 Unidad de Hortofruticultura, Centro de Investigación y Tecnología Agroalimentaria de Aragón (CITA), Instituto \\ Agroalimentario de Aragón-IA2 (CITA-Universidad de Zaragoza), Avda. Montañana, 930, 50059 Zaragoza, Spain; ${ }^{2}$ \\ Instituto de Hortofruticultura Subtropical y Mediterránea "La Mayora” (IHSM-UMA-CSIC), 29750 Algarrobo-Costa, \\ Málaga, Spain; ${ }^{3}$ Pomology Department, Estación Experimental Aula Dei-CSIC, Av. Montañana, 1005, 50059 \\ Zaragoza, Spain. \\ aE-mail: jlora@eelm.csic.es
}

\begin{abstract}
Apricot (Prunus armeniaca) is a member of the Rosaceae originated in China. Most of the European apricot cultivars have been traditionally considered selfcompatible (SC) although S-RNase-based-Gametophytic Self-Incompatibility (GSI), a common incompatibility mechanism found in the Rosaceae and genetically determined by a locus $(S)$ with multiple alleles, is common in the species. This locus encodes an allele-specific $S$-RNase, expressed in the style, which inhibits the growth of pollen tubes with the same $S$ alleles. In the last years, an important renewal of plant material is taking place worldwide, with the introduction of new cultivars from different breeding programs. The use of self-incompatible (SI) parental genotypes has resulted in an increasing number of SI new cultivars with unknown pollination requirements. In order to establish the incompatibility relationships among apricot cultivars, in this work we perform a $S$-RNase allele identification in a group of 48 cultivars from different breeding programs. The $S$-alleles of each cultivar were determined by PCR amplification of the $S$-RNase gene. The results allowed allocating the cultivars in their corresponding incompatibility groups, a highly valuable tool for fruit growers to design apricot orchards, and for breeders to choose parental genotypes in breeding programs.
\end{abstract}

Keywords: Prunus armeniaca, self-incompatibility, $S$-genotype, $S$-alleles

\section{INTRODUCTION}

Apricot (Prunus armeniaca L.) was originated in Central Asia where it has been cultivated for millennia and from where it spread worldwide. Apricot cultivars can be classified in six main ecogeographical groups (Layne et al., 1996). The majority of apricot cultivars originated in Middle-Asian and Iranian-Caucasian groups are self-incompatible (SI), however, most of the European apricot cultivars have been traditionally considered selfcompatible (SC) (Hormaza et al., 2007).

In the last years, the introduction of new cultivars from different breeding programs has provided an important renewal of plant material (Zhebentyayeva et al., 2012). Although most traditional apricot cultivars are self-compatible (Burgos et al., 1997), the use of selfincompatible parental genotypes in breeding programs (Hormaza et al., 2007) has resulted in the recent release of new self-incompatible cultivars, which need to be grown together with cross-compatible cultivars to ensure an appropriate yield. However, the pollination requirements of many of these new cultivars are unknown.

Self-incompatibility in Rosaceae is based on cell-cell recognition that is determined genetically by a Gametophytic Self-Incompatibility System (GSI) that acts through the inhibition of the pollen tube growth in the style. This mechanism is controlled by a multiallelic locus named $S$, encoding two linked genes that determine the pistil and pollen genotype (Charlesworth et al., 2005). A ribonuclease (S-RNase) determines the allele specificity of the 
style (Tao et al., 1997) and an F-box protein (SFB) determines pollen allele specificity (Ushijima et al., 2003).

The identification of the $S$-RNase gene in apricot (Romero et al., 2004; Sutherland et al., 2004) allowed developing an $S$-allele genotyping PCR strategy, similar to those developed for cherry and almond (Sutherland et al., 2004). In the first PCR study of $S$-allele genotyping in apricot reported, seven self-incompatibility alleles $\left(S_{1}\right.$ to $\left.S_{7}\right)$ and one allele for selfcompatibility $\left(S_{c}\right)$ were identified (Vilanova et al., 2005). Afterwards nine additional $S$-alleles $\left(S_{8}-S_{16}\right)$ were identified by Halász et al. (2005). These studies allowed the determination of different apricot $S$-genotypes from different countries (Halász et al., 2010; Kodad et al., 2013; Lora et al., 2017). Most of these $S$-alleles have been characterized using detection of $S$-locus genes by PCR fragment amplification and some of them have also been sequenced. The PCRanalysis can show little differences in the fragment size of some $S$-alleles, even if was carried out on an automatic sequencer (Lora et al., 2017).

In this work, we determine the $S$-allele identification of 48 apricot cultivars. The genetic identification of some $S$-alleles that could not be distinguished in previous works has been solved by a sequencing approach. Each cultivar has been assigned to its corresponding incompatibility group.

\section{MATERIALS AND METHODS}

Adult trees of 48 apricot cultivars from different collections and orchards of Aragón (Spain) were used, including traditional and new cultivars from different breeding programs (Table 1).

Genomic DNA was extracted from young leaves and used for $S$-allele genotyping following the protocol described by Hormaza (2002) and using the DNeasy Plant Mini Kit (Qiagen). For the PCR analyses, the primer pair SRc-F and SRc-R (Vilanova et al., 2005) was used to amplify the first intron of the apricot $S$-RNase in a PCR reaction of $15 \mu \mathrm{L}$, containing 10x NH4 Reaction Buffer, $25 \mathrm{mM} \mathrm{Cl}_{2} \mathrm{Mg}, 2.5 \mathrm{mM}$ of each dNTP, $10 \mu \mathrm{M}$ of each primer, $100 \mathrm{ng}$ of genomic DNA and $0.5 \mathrm{U}$ of BioTaq ${ }^{\mathrm{TM}}$ DNA polymerase (Bioline, London, UK). The temperature profile used had an initial step of $3 \mathrm{~min}$ at $94^{\circ} \mathrm{C}, 35$ cycles of $1 \mathrm{~min}$ at $94^{\circ} \mathrm{C}, 1 \mathrm{~min}$ at $55^{\circ} \mathrm{C}$ and $3 \mathrm{~min}$ at $72^{\circ} \mathrm{C}$, and a final step of $5 \mathrm{~min}$ at $72^{\circ} \mathrm{C}$. For the amplification of the second intron, the primers Pru-C2 and Pru-C4R were used as recommended in Vilanova et al. (2005), but with the addition of 10 cycles and $55^{\circ} \mathrm{C}$ of annealing temperature as indicated in Sonneveld et al. (2003).

The PCR fragments were isolated using NucleoSpin Gel and PCR Clean-up (MachereyNagel). Cloning was performed using CloneJET PCR Cloning Kit (Thermo) and by electroporation in E. coli Single-Use JM109 Competent Cells (Promega). The search for similarities was performed in NCBI blast (http://www.ncbi.nlm.nih.gov/BLAST, version 2.2.10).

\section{RESULTS AND DISCUSSION}

The $S$-alleles were characterized by using the primers SRc-F/SRc-R that allowed amplifying the first intron (Vilanova et al., 2005) and identifying eight alleles. Two of them, $S_{1}$ and $S_{7}$, showed a similar fragment size of $400 \mathrm{bp}$ and, in those cases, the primers Pru-C2/PruC4R could distinguish both alleles, showing a fragment size of $2260 \mathrm{bp}$ for the $S_{1}$ allele or 900 bp for $S_{7}$ according to Vilanova et al. (2005). Primers Pru-C2/Pru-C4R were initially designed to amplify the second intron in Prunus avium (Tao et al., 1999).

In a previous study we identified the $S$-alleles of 40 apricot cultivars, some of them showing a $420 \mathrm{bp}$ or $430 \mathrm{bp}$ fragment that was assigned as $S_{x}$ and $S_{y}$ respectively (Lora et al., 2017). These band sizes are close to the $S_{6}$ allele, which has been reported as 424 bp (Kodad et al., 2013) or $423 \mathrm{bp}$ (Halasz et al., 2010). To elucidate if $S_{x}\left(420 \mathrm{bp}\right.$ ) and $S_{y}(430 \mathrm{bp}$ ) correspond to $S_{6}$ or are different alleles, both fragments were cloned and sequenced, resulting 
in a sequence of $414 \mathrm{bp}$ for $S_{x}$ and $421 \mathrm{bp}$ for $S_{y}$. These results showed differences of several bp from the PCR fragment analysed by an automatic sequencer and the real sequence. Differences in fragment size were also found in the $S_{2}(334 \mathrm{bp}$ herein, $327 \mathrm{bp}$ in Vilanova et al., 2005; 332 bp in Kodad et al., 2013) and $S_{c}$ (358 bp herein; 353 bp in Vilanova et al., 2005; $355 \mathrm{bp}$ in Kodad et al., 2013) alleles.

The alignment of the $S_{y}$ allele in the sequence database showed a $99 \%$ identity $(100 \%$ cover) with an unpublished allele, $S_{52}$ (KF951503.2). Since the $S_{6}$ allele has not been previously sequenced, allele $S_{52}$ could indeed correspond to the $S_{6}$ allele. The $S_{6}$ allele could also be identified with the primers Pru-C2/Pru-C4 showing a PCR-fragment of around 1400 bp that includes the second intron (Vilanova et al., 2005). Thus, we amplified it using these primers. The PCR results showed a fragment of 1400 bp strongly suggesting that $S_{y}, S_{6}$ and $S_{52}$ are the same allele. Moreover, the primers Pru-C2/Pru-C4 enclose a sequence of $1386 \mathrm{bp}$ in the allele $S_{52}$. Thus, in this work, allele $S_{6}$ was assigned to $S_{y}$.

The sequence of the $S_{x}$ allele showed sequence similarity to $S$-alleles, but not $S$-alleles of Prunus armeniaca. The second intron of this allele was amplified with the primers PruC2/Pru-C4, showing a PCR-fragment of around $700 \mathrm{bp}$. Its cloning, sequencing and alignment revealed a $99 \%$ identity (100\% cover) with the allele $S_{9}$ (AY853594, Feng et al., 2006) and, consequently, the allele $S_{9}$ was assigned to the allele $S_{x}$. These results have enabled the identification of 12 cultivars that were previously identified with the allele $S_{x}$ or $S_{y}$ (Lora et al., 2017).

In this work, the $S$-RNase genotype has been analysed in a group of 48 apricot cultivars (Table 1). The $S c$ allele was identified in 13 cultivars, which were considered self-compatible (Vilanova et al., 2006). The cultivars 'Katy', 'Lorna' and 'Palsteyn' were also assigned to the self-compatible group, because they have been described as self-compatible although they did not exhibit the $S c$ allele (Zuriaga et al., 2013; Herrera et al., 2017; Lora et al., 2017). Although two alleles were identified in most cultivars, a unique allele was identified in 13 cultivars. Nineteen cultivars were assigned to seven incompatibility groups. Results herein showed differences in the $S$-RNase genotype of 'Palsteyn' $\left(S_{1} S_{2}\right)$ and 'Lorna' $\left(S_{1} S_{2}\right)$ reported in previous studies as $S_{1} S c$ (Raz et al., 2009) and $S_{2}$ (Donoso et al., 2009).

These results are valuable for the selection of parental genotypes in apricot breeding programs and for an appropriate distribution of pollenizer cultivars in commercial orchards. Moreover, these results underline the need for a sequencing approach for accurate $S$-allele identification that unifies PCR fragment size reports.

\section{ACKNOWLEDGEMENTS}

Financial support for this research was provided by Ministerio de Economía y Competitividad (MINECO) - European Regional Development Fund, European Union (AGL2013-43732-R, AGL2016-77267-R and AGL2015-74071-JIN); Instituto Nacional de Investigación Agraria (INIA) (RFP2015-00015-00, RTA2014-00085-00); Gobierno de Aragón - European Social Fund, European Union (Grupo Consolidado A-43) and by Agroseguro S.A. We thank Yolanda Verdún for technical assistance.

\section{Literature cited}

Burgos, L., Egea, J., Guerriero, R., Viti, R., Monteleone, P., and Audergon, J.M. (1997). The self-compatibility trait of the main apricot cultivars and new selections from breeding programmes. J. Hortic. Sci. 72, 147-154 http://dx.doi.org/10.1080/14620316.1997.11515501.

Charlesworth, D., Vekemans, X., Castric, V., and Glemin, S. (2005). Plant self-incompatibility systems: a molecular evolutionary perspective. New Phytol. 168, 61-69 https://doi.org/10.1111/j.1469-8137.2005.01443.x. 
Donoso, J.M., Aros, D., Meneses, C., and Infante, R. (2009). Identification of $S$-alleles associated with selfincompatibility in apricots (Prunus armeniaca L.) using molecular markers. Journal of Food, Agriculture and Environment 7(3-4), 270-273.

Feng, J., Chen, X., Wu, Y., Liu, W., Liang, Q., and Zhang, L. (2006). Detection and transcript expression of S-RNase gene associated with self-incompatibility in apricot (Prunus armeniaca L.). Mol. Biol. Rep. 33, 215-221 http://dx.doi.org/10.1007/s11033-006-0011-x.

Halasz, J., Hegedus, A., Herman, R., Stefanovits-Banyai, E., and Pedryc, A. (2005). New self-incompatibility alleles in apricot (Prunus armeniaca L.) revealed by stylar ribonuclease assay and S-PCR analysis. Euphytica 145, 57-66 http://dx.doi.org/10.1007/s10681-005-0205-7.

Halasz, J., Pedryc, A., Ercisli, S., Yilmaz, K.U., and Hegedus, A. (2010). S-genotyping supports the genetic relationships between Turkish and Hungarian apricot germplasm. J. Amer. Soc. Hort. Sci. 135, 410-417.

Herrera, S., Lora, J., Hormaza, J.I., Herrero, M. and Rodrigo, J. (2018). Evaluación de la autocompatibilidad en nuevas variedades de albaricoquero mediante microscopía de fluorescencia. Acta Hort. In press.

Hormaza, J.I. 2002. Molecular characterization and similarity relationships among apricot (Prunus armeniaca L.) genotypes using simple sequence repeats. Theor. Appl. Genet. 104, 321-328 https://doi.org/10.1007/s001220100684.

Hormaza, J.I., Yamane, H., and Rodrigo, J. (2007). Apricot. In Genome Mapping and Molecular Breeding in Plants, Volume 4 Fruits and Nuts, C. Kole, ed. (Berlin, Heidelberg: Springer), p.171-187.

Kodad, O., Hegedűs, A., Socias i Company, R., and Halász, J. (2013). Self-(in)compatibility genotypes of Moroccan apricots indicate differences and similarities in the crop history of European and North African apricot germplasm. BMC Plant Biol. 13, 196 https://doi.org/10.1186/1471-2229-13-196.

Layne R.E.C, Bailey C.H., and Hough L.F. (1996) Apricots. In Fruit Breeding, Volume 1 Tree and Tropical Fruits, J. Janick and J.N. Moore, eds. (New York, USA: JohnWiley \& Sons), p.79-111.

Lora, J., Hormaza, J.I., Herrero, M., and Rodrigo, J. (2018). Self-incompatibility and $S$-allele identification in new apricot cultivars. Acta Hortic. In press.

Raz, A., Stern, R.A., Bercovich, D., and Goldway, M. (2009). SFB-based $S$-haplotyping of apricot (Prunus armeniaca) with DHPLC. Plant Breeding 128(6), 707-711 https://doi.org/10.1111/j.1439-0523.2008.01613.x.

Romero, C., Vilanova, S., Burgos, L., Martínez-Calvo, J., Vicente, M., Llácer, G., and Badenes, M.L. (2004). Analysis of the $S$-locus structure in Prunus armeniaca L. Identification of S-haplotype specific S-RNase and F-box genes. Plant Mol. Biol. 56, 145-157 https://doi.org/10.1007/s11103-004-2651-3.

Sonneveld, T., Tobutt, K.R., and Robbins, T.P. (2003). Allele-specific PCR detection of sweet cherry selfincompatibility $(S)$ alleles $S 1$ to $S 16$ using consensus and allele-specific primers. Theor. Appl. Genet. 107, 10591070 https://doi.org/10.1007/s00122-003-1274-4.

Sutherland, B.G., Robbins, T.P., and Tobutt, K.R. (2004). Primers amplifying a range of Prunus $S$-alleles. Plant Breed. 123, 582-584 https://doi.org/10.1111/j.1439-0523.2004.01016.x.

Tao, R., Yamane, H., Sassa, H., Mori, H., Gradziel, T.M., Dandekar, A.M., and Sugiura, A. (1997). Identification of stylar RNases associated with gametophytic self-Incompatibility in almond (Prunus dulcis). Plant Cell Physiol. 38, 304311 https://doi.org/10.1093/oxfordjournals.pcp.a029167.

Tao, R., Yamane, H., Sugiura, A., Murayama, H., Sassa, H., and Mori, H., (1999). Molecular typing of $S$-alleles through identification, characterization and cDNA cloning for S-RNases in sweet cherry. J. Am. Soc. Hortic. Sci. 124, 224233.

Ushijima, K., Sassa, H., Dandekar, A.M., Gradziel, T.M., Tao, R., and Hirano, H. (2003). Structural and transcriptional analysis of the self-incompatibility locus of almond: identification of a pollen-expressed F-box gene with haplotype-specific polymorphism. The Plant Cell 15(3), 771-81 http://dx.doi.org/10.1105/tpc.009290

Vilanova, S., Romero, C., Llacer, G., Badenes, M.L., and Burgos, L. (2005). Identification of self-(in)compatibility alleles in apricot by PCR and sequence analysis. J. Amer. Soc. Hort. Sci. 130, 893-898. 
Vilanova, S., Badenes, M.L., Burgos, L., Martinez-Calvo, J., Llacer, G. and Romero, C. (2006). Self-Compatibility of Two Apricot Selections Is Associated with Two Pollen-Part Mutations of Different Nature. Plant Physiology 142(2), 629-641. https://doi.org/10.1104/pp.106.083865

Zhebentyayeva, T., Ledbetter, C., Burgos, L., and Llacer, G. (2012). Apricots. In Handbook of Plant Breeding, Volume 8 Fruit Breeding, $1^{\text {st }}$ edn, M.L. Badenes, and D.H. Byrne, eds. (New York, USA: Springer), p.415-458.

Zuriaga, E., Muñoz-Sanz, J.V, Molina, L., Gisbert, A.D., Badenes, M.L., and Romero, C. (2013). An S-locus independent pollen factor confers self-compatibility in "Katy" apricot. PLoS One 8, e53947 https://doi.org/10.1371/journal.pone.0053947

Table 1. Incompatibility groups and $S$-genotype of 48 apricot cultivars.

I.G. S-genotype Cultivars analysed in this study

\begin{tabular}{|c|c|c|}
\hline I & $S_{1} S_{2}$ & Goldrich, Hargrand \\
\hline III & $S_{2} S_{6}$ & ASF0401, Bergarouge, Moniqui \\
\hline VIII & $S_{6} S_{9}$ & ASF0402, ASF0405, Orangered ${ }^{1}$, Stark Early Orange, Wonder Cot \\
\hline XVIII & $\mathrm{S}_{2} \mathrm{~S}_{3}$ & Mayacot, Sun Glo \\
\hline XIX & $\mathrm{S}_{2} \mathrm{~S}_{9}$ & Goldstrike, Magic Cot \\
\hline$X X$ & $\mathrm{~S}_{3} \mathrm{~S}_{9}$ & Durobar, Flodea, Henderson, Tsunami \\
\hline XXI & $S_{7} S_{9}$ & Goldbar \\
\hline $\begin{array}{l}\text { Self-compatible } \\
\text { cultivars }\end{array}$ & \multicolumn{2}{|c|}{$\begin{array}{l}\text { ASF0404 }\left(S_{c}\right) \text {, Bergecot }\left(S_{2} S_{c}\right) \text {, Canino }\left(S_{2} S_{c}\right) \text {, Charisma }\left(S_{7} S_{c}\right) \text {, Faralia }\left(S_{6} S_{c}\right) \text {, Flopria } \\
\left(S_{9} S_{c}\right) \text {, Kioto }\left(S_{c}\right) \text {, Mitger }\left(S_{c}\right) \text {, Paviot }\left(S_{2} S_{c}\right) \text {, Pricia }\left(S_{3} S_{c}\right) \text {, Soledane }\left(S_{c}\right) \text {, Tadeo }\left(S_{c}\right) \text {, Tom } \\
\operatorname{Cot}\left(S_{9} S_{c}\right) \text {, Katy }\left(S_{1} S_{2}\right) \text {, Lorna }{ }^{1}\left(S_{1} S_{2}\right) \text {, Palsteyn }{ }^{1}\left(S_{1} S_{2}\right)\end{array}$} \\
\hline Unclassified & \multicolumn{2}{|c|}{$\begin{array}{l}\text { Aurora }\left(S_{9}\right) \text {, Big Red }\left(S_{1}\right) \text {, Early Queen }\left(S_{2}\right) \text {, Golden Sweet }\left(S_{3}\right) \text {, Harcot }\left(S_{4}\right) \text {, JNP }\left(S_{9}\right) \text {, Lilly } \\
\operatorname{Cot}\left(S_{3}\right) \text {, Muñoz }\left(S_{2}\right) \text {, Pandora }\left(S_{2}\right) \text {, Perle } \operatorname{Cot}\left(S_{9}\right) \text {, Pinkcot }\left(S_{9}\right) \text {, Veecot }\left(S_{2}\right) \text {, Westley }\left(S_{2}\right)\end{array}$} \\
\hline
\end{tabular}

${ }^{1}$ Cultivars in which the $S$-RNase genotype reported herein differs from that reported in other studies. 